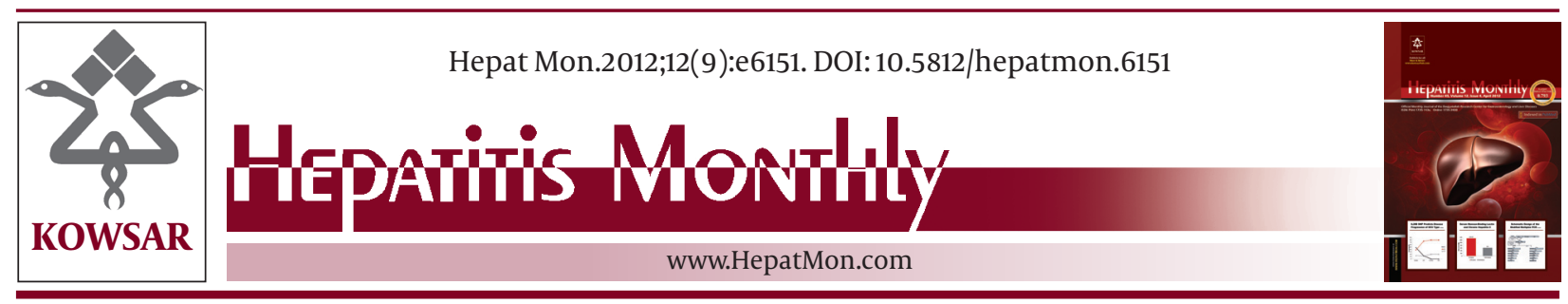

\title{
Real Response to Therapy in Chronic Hepatitis C Virus Patients: A Study From Iran
}

\author{
Najmeh Namazee ${ }^{1}$, Shahnaz Sali ${ }^{1}$, Sorour Asadi ${ }^{1}$, Mostafa Shafiei ${ }^{2}$, Bita Behnava ${ }^{2}$, Seyed \\ Moayed Alavian ${ }^{2^{*}}$ \\ ${ }^{1}$ Infectious Disease and Tropical Medicine Research Center, Shahid Beheshti University of Sciences, Tehran, IR Iran \\ ${ }^{2}$ Research Center for Gastroenterology and Liver Diseases, Baqiatallah University of Sciences, Tehran, IR Iran
}

\begin{tabular}{l}
\hline A R T I C L E I N F O \\
\hline Article type: \\
Original Article \\
Article history: \\
Received:10 May 2012 \\
Revised:26 Jun 2012 \\
Accepted: 06 Jul 2012 \\
\hline
\end{tabular}

Keywords:

Hepatitis C, Chronic

Peginterferon Alfa-2a

Ribavirin

\begin{abstract}
A B S T R A C T
Background: Despite significant advances in the treatment of chronic hepatitis $\mathrm{C}$ in the past decades, factors which can affect response rates to combination therapy; peginterferon and ribavirin, are still under study and reaching sustained virological response (SVR) is affected by several different factors.

Objectives: To investigate predictor factors contributing to SVR in Iranian patients.

Patients and Methods: The present non-randomized, clinical trial was conducted on 100 patients referred to the Tehran Hepatitis Center in 2009-2011. The patients were administered combined peginterferon $\alpha$-2a-ribavirin treatment, based on the standard protocol of the Iranian Ministry of Health. At the end of the treatment, the SVR rate and predictors were evaluated.

Results: The mean age of the patients was 42 and $78 \%$ were male. Genotype 1a was the most common (70\%) and $55 \%$ of patients were treatment naïve. The outcomes showed that $12 \%, 16 \%$ and $22 \%$ patients were; non-responders, breakthroughs and relapsers, respectively, while $50 \%$ of the patients reached SVR. Patients reaching SVR were aged 40 years or lower, they were less likely to have been a non-responder in prior treatments, more likely to have a non-1a genotype and a higher number had an HCV RNA of less than $600000 \mathrm{IU} / \mathrm{ml}$. The multivariate analysis showed that an age of 40 or lower $(\mathrm{OR}=3.74$, CI95\% $=1.52-9.22)$, a non-1a genotype $(\mathrm{OR}=3.71$, CI 95\% $=1.40-9.81)$ and an HCV RNA less than $600000 \mathrm{IU} / \mathrm{ml}(\mathrm{OR}=2.52, \mathrm{CI} 95 \%=1.03-6.15)$ may be useful SVR predictors.

Conclusions: The findings of the present study showed that half of the patients reached SVR through combined peginterferon $\alpha-2 \mathrm{a}$ and ribavirin treatment, the majority of whom had genotype 3a and a minority had genotype 1a. In addition, an age of 40 or lower, non-1a genotype and a viral load less than $600000 \mathrm{IU} / \mathrm{ml}$ were strong SVR predictors.
\end{abstract}

Published by Kowsar Corp, 2012. cc 3.0.

Implication for health policy/practice/research/medical education:

Chronic hepatitis C is a global healthcare problem, affecting approximately $3 \%$ of world population; with sustain virological response (SVR) rates after treatment ranging from 34 to $61 \%$. This article evaluates the predictors for SVR and also complications of combination therapy with peginterferon $\alpha$-2a and ribavirin.

\section{Please cite this paper as:}

Namazee N, Sali S, Asadi S, Shafiei M, Behnava B, Alavian SM. Real Response to Therapy in Chronic HCV Patients: A Study From Iran. Hepat Mon. 2012;12(9):e6151. DOI: 10.5812/hepatmon.6151

\footnotetext{
* Corresponding author: Seyed Moayed Alavian, Research Center For Gastroenterology and Liver Diseases, Baqiatallah University of Sciences, Mollasadra St.,

Vanak Sq., P. O. Box: 141553651, Tehran, IR Iran. Tel:+98-2188067114, Fax:+98-2188945188, E-mail: editor@hepatmon.com

DOI:10.5812/hepatmon.6151

(C) 2012 Baqiyatallah Research Center for Gastroentrology and liver diseases; Published by Kowsar Corp.

This is an Open Access article distributed under the terms of the Creative Commons Attribution License (http://creativecommons.org/licenses/by/3.0), which permits unrestricted use, distribution, and reproduction in any medium, provided the original work is properly cited.
} 


\section{Background}

The treatment regimen of chronic hepatitis $C$ has changed significantly over the past decades in antiviral treatment of hepatitis $\mathrm{C}$ virus (HCV) infection and combination therapy of peginterferon-ribavirin has become a standard around the world (1) and in Iran, too (2). The efficacy of antiviral treatment of $\mathrm{HCV}$ is measured through sustained virological response (SVR), which is operationally defined as the absence of HCV RNA (detectable through RT-PCR) within six months of treatment termination(3). Reaching SVR not only prevents advancement towards cirrhosis, HCC and liver failure, but it may also improve a patient's quality of life(4-6). In addition, the majority of affected patients remain in blood and liver remission with long-term effects of $99-100 \%(7,8)$. Although combination therapy of pegylated interferon and ribavirin significantly increases SVR and increases the probability of reaching SVR by 50\% (9), the degree of response depends on a variety of factors and these may also differ in various patient populations (10). Viral genotype, viral load, patient age, BMI, race, environment and several other factors have been shown to correlate with SVR (11-16). Prolonged antiviral treatment with numerous complications and medical costs on the one hand and the multiplicity of factors affecting response to treatment on the other hand, warrant the identification of the predictive variables of reaching SVR as a leading morbidity prevention factor in selected populations (17). Although a few studies on the effects of this therapy on HCV have already been conducted in Iran, they have used either a small sample size or have not considered predictor variables (18-23). For instance, Alavian et al., studied SVR predictor variables, but their research only included hemophilic patients (12).

\section{Objectives}

The present study attempts to study a range of predictors for reaching SVR including; patient characteristics, viral characteristics and the results of tests such as end-of-treatment leukopenia, neutropenia, thrombocytopenia and aspartate aminotransferase (AST) to platelet ratio index or APRI, in chronic hepatitis $C$ patients receiving combination therapy of peginterferon $\alpha$-2a and ribavirin.

\section{Patients and Methods}

\subsection{Study Design and Patient Selection}

The present non-randomized, open-label clinical trial was conducted in the 2009-2011 period. A sample of $100 \mathrm{HCV}$ patients with a minimum age of 15 was selected from the patients referred to the Tehran Hepatitis Center. This center is a referral center which receives patients from all parts of Iran. The selected patients had chronic hepatitis C, evidenced by a liver biopsy performed not more than one year before the study screening. They had a HCV RNA level higher than $50 \mathrm{U} / \mathrm{ml}$ six months before the study and they were not under treatment. Other entry criteria included an $\mathrm{Hb}>12 \mathrm{~g} / \mathrm{dl}$, an absolute neutrophil count (ANC) $>1500 / \mathrm{mm}^{3}$ and blood platelets higher than $80000 / \mathrm{mm}^{3}$.

Exclusion criteria included simultaneous infection with hepatitis B or human immunodeficiency virus (HIV), active liver disease, existence of liver disease with a cause other than hepatitis C, hepatocellular carcinoma (HCC), liver transplantation history, uncontrolled diabetes mellitus, malignant neoplastic disease, severe cardiac or pulmonary disease, autoimmune disorders, retinopathy, morbid obesity (weight over $125 \mathrm{~kg}$ ), severe depression, uncontrolled psychotic disorders and existing drug addiction.

The research goals and procedures and the complications of the medications were explained to the patients. Written consents were obtained from all patients. The present study is in full compliance with the ethical principles of the Declaration of Helsinki and the 26 ethical principles mandated by the Iranian Ministry of Health. In addition, an ethical approval was obtained from the National Committee on Medical Ethics, which was registered under IRT138811193307N1 at the Iranian Registry of Clinical Trials (www.irct.ir).

\subsection{Intervention}

A checklist was used to record demographic information; age, gender, HCV risk factor, patients' weight and height and prior treatment history (naïve, non-responder to previous treatments administered through conventional IFN or relapser to previous treatments). The primary tests included CBC with differential, thyroid function tests (TFTs), liver function tests (LFTs), creatinine and lipid profile. APRI was determined through the following formula:

$$
A P R I=\frac{(A S T(U / L) / 40(\text { Upper Limit Normal })) * 100}{P L T(/ L) / 10^{9}}
$$

The HCV genotype was determined through the method explained in reference (19). The HCVRNA was determined using a COBAS Amplicor HCV Monitor, v2.0 (Roche Diagnostics, Branchburg, NJ, USA) with a precision value of $50 \mathrm{IU} / \mathrm{ml}$. The patients underwent intervention treatment taking peginterferon $\alpha-2 a$ (Pegasys $®$, Roche, and Basel, Switzerland) and ribavirin (Copegus $₫$, Roche) in accordance with the standard protocol of the Iranian Ministry of Health. This protocol consisted of, 180 $\mathrm{ug}$ of peginterferon $\alpha$-2a administered subcutaneously once per week. In genotype 1 and 4 patients, who weighed less than $75 \mathrm{~kg}$, they were given ribavirin administered orally in $1000 \mathrm{mg}$ daily doses, and in patients who weighed over $75 \mathrm{~kg}$ the medication was administered orally in $1200 \mathrm{mg}$ daily doses. In genotype 2 and 3 patients, ribavirin was administered orally in $800 \mathrm{mg}$ daily doses. The treatment length in genotype 1 and 4 patients was 48 weeks and it was 24 weeks in genotype 2 and 3 patients. In addition, patients were followed up six months after the intervention for complications, lab tests and SVR. Patients were monitored through monthly referrals while taking the medications.

\subsection{Outcome Measurement}

The HCV RNA was measured at the outset of the interven- 
tion, in weeks 12, 24, 48 and also six months after the end of treatment. The main outcome was SVR levels which were operationally defined as undetectable HCV RNA at the end of the follow-up period. The secondary outcomes included; early viral response (EVR), undetectable HCV RNA or a decrease of more than 2 log10 IU compared to the level at the 12th week of the intervention and the end of treatment response (ETR), undetectable HCVRNA at the end of treatment. On the basis of the obtained outcomes, patients were divided into four groups; non-responder patients with no EVR, breakthrough patients with EVR but without ETR, relapse patients with ETR but without SVR, and patients who had reached SVR. Non-responder patients were considered as treatment failures and their treatment was discontinued.

\subsection{Assessment of Safety}

Lab tests were administered monthly to the patients and any drug complications were addressed through telephone or face-to-face contact both during the intervention and during the follow-up period. The severity of the complications was classified according to WHO categorization as mild, moderate and severe or life threatening. Mild to moderate complications were countered through a decrease in medication dosage or through the prescription of appropriate drugs. Lab criteria for dose reduction of peginterferon $\alpha-2 a$ included $500-750 / \mathrm{mm}^{3}$ neutrophils or $30000-50000 / \mathrm{mm} 3$ platelets. The administration of peginterferon $\alpha-2 a$ was discontinued in cases of neutrophils less than 500/mm3, platelets less than $30000 / \mathrm{mm}^{3}$ and hemoglobin levels dropping below $7 \mathrm{~g} / \mathrm{dl}$ (12). In addition, the ribavirin dosage was reduced in cases of hemoglobin levels falling below $10 \mathrm{~g} / \mathrm{dl}$ and it would be stopped if hemoglobin dropped below 8.5g/ $\mathrm{dl}$ (12). When abnormalities in these lab tests occurred, not only was drug dosage reduced, but the tests also had to be repeated within one or two weeks in order to reach normal levels. The drug dosage was increased again once the tests became normal, otherwise, the treatment would be stopped. G-CSF was prescribed when prolonged dose reduction was required because of neutropenia.

\subsection{Statistical Analysis}

Data were analyzed using SPSS 13.0 for Windows (SPSS Inc., Chicago, IL, USA). The qualitative variables were described using frequency and percentage and the quantitative variables were described using the mean and standard deviation. Data from all patients receiving medication were included in the analysis. Patients reaching SVR were placed in the SVR positive group and the rest of the patients were labeled as the non-SVR group. A chi-square test was used to compare the qualitative variables and an independent sample t-test was performed to compare the quantitative variables. Multivariate logistic regression was performed to evaluate SVR predictors. For this purpose, variables with a $P$ value less than 0.1 in the univariate analysis were considered as predictors of SVR(as the outcome). Variables were entered into the model using the forward conditional with a $P=0.05$, and removed with a $P=0.1$.

\section{Results}

\subsection{Patient Characteristics}

Seventy-eight percent of the patients were male. The mean age of the patients was 42 years, while 41 patients (41\%) were 40 years or younger. A total of 68 patients (68\%) had a BMI value of 25 or lower. Intravenous drug user (IVDU) and blood transfusion were the commonest risk factors of HCV. In terms of history, 55 (55\%) patients were treatment naïve and the most common virus genotype was 1a. At the outset, an AST or ALT equal to or higher than 40U/L were seen in 64

\begin{tabular}{|c|c|}
\hline Patient Characteristics & Value \\
\hline Male, No. (\%) & $78(78)$ \\
\hline Female, No.(\%) & $22(22)$ \\
\hline Age, y, mean \pm SD & $42 \pm 12$ \\
\hline Age range & $17-73$ \\
\hline $\mathrm{BMI}\left(\mathrm{kg} / \mathrm{m}^{2}\right)$, mean $\pm \mathrm{SD}$ & $24.2 \pm 3.1$ \\
\hline BMI range & $18.3-32.7$ \\
\hline \multicolumn{2}{|l|}{ HCV risk factors } \\
\hline IVDU, No. (\%) & $33(33)$ \\
\hline Transfusion, No.(\%) & $39(39)$ \\
\hline Others (surgery, tattoo, etc.) No. (\%) & $28(28)$ \\
\hline \multicolumn{2}{|l|}{ Genotype } \\
\hline 1a, No. (\%) & $70(70)$ \\
\hline 1a/3a, No. (\%) & $4(4)$ \\
\hline 1b, No. (\%) & $10(10)$ \\
\hline 3a, No. (\%) & $15(15)$ \\
\hline Non typeable, No. (\%) & $1(1)$ \\
\hline \multicolumn{2}{|l|}{ Previous treatment } \\
\hline Naïve, No.(\%) & $55(55)$ \\
\hline Non-Responder, No. (\%) & $25(25)$ \\
\hline Relapser, No. (\%) & $20(20)$ \\
\hline $\mathrm{WBC}\left(\mathrm{mm}^{3}\right)$, mean $\pm \mathrm{SD}$ & $6027 \pm 1859$ \\
\hline $\operatorname{PMN}\left(\mathrm{mm}^{3}\right)$, mean $\pm \mathrm{SD}$ & $3356 \pm 1323$ \\
\hline $\mathrm{Hb},(\mathrm{g} / \mathrm{dl})$, mean $\pm \mathrm{SD}$ & $14.6 \pm 1.8$ \\
\hline $\operatorname{PLT}\left(\mathrm{mm}^{3}\right)$, mean $\pm \mathrm{SD}$ & $188360 \pm 70821$ \\
\hline $\mathrm{AST},(\mathrm{U} / \mathrm{L})$, mean $\pm \mathrm{SD}$ & $64 \pm 51$ \\
\hline AST Range & $11-300$ \\
\hline $\mathrm{ALT},(\mathrm{U} / \mathrm{L})$, mean $\pm \mathrm{SD}$ & $87 \pm 98$ \\
\hline ALT Range & $10-800$ \\
\hline HCV RNA, (IU/ml), mean \pm SD & $1205475 \pm 1446704$ \\
\hline HCV RNA Range & $2040-9710000$ \\
\hline
\end{tabular}

Abbreviations: ALT, alanine aminotransferase; AST, aspartate aminotransferase; BMI, body mass index; Hb, hemoglobin; HCV, hepatitis C virus; IVDU, intravenous drug user; PLT, platelets; PMN, polymorphoneuclear cells; WBC, white blood cells. 


\begin{tabular}{|c|c|c|c|}
\hline & SVR, No. (\%) & Non SVR, No. (\%) & Total, No. (\%) \\
\hline \multicolumn{4}{|l|}{ Previous history } \\
\hline Naïve & $31(56)$ & $24(44)$ & $55(100)$ \\
\hline Relapser & $12(60)$ & $8(40)$ & $20(100)$ \\
\hline Non-Responder & $7(28)$ & $18(72)$ & $25(100)$ \\
\hline \multicolumn{4}{|l|}{ HCV Genotype } \\
\hline $1 \mathrm{a}$ & $29(42)$ & $41(58)$ & $70(100)$ \\
\hline $1 a / 3 a$ & $2(50)$ & $2(50)$ & $4(100)$ \\
\hline $1 \mathrm{~b}$ & $6(60)$ & $4(40)$ & $10(100)$ \\
\hline $3 a$ & $12(80)$ & $3(20)$ & $15(100)$ \\
\hline Non-typeable & $1(100)$ & - & $1(100)$ \\
\hline
\end{tabular}

Abbreviation: SVR, sustained virological response

Table 3. Univariate Analysis Results Between Patients With and Without Sustained Virological Response (SVR)

\begin{tabular}{|c|c|c|c|}
\hline & SVR & Non SVR & Pvalue \\
\hline Age, $y(\leq 40)$, No. $(\%)$ & $27(54)$ & $14(28)$ & $0.008^{\mathrm{a}}$ \\
\hline Sex, (male), No. (\%) & $40(80)$ & $38(76)$ & $0.629^{a}$ \\
\hline BMI $\left(\mathrm{kg} / \mathrm{m}^{2}\right)(>25)$, No. (\%) & $18(36)$ & $14(28)$ & $0.391^{\mathrm{a}}$ \\
\hline HCV risk factor (IVDU), No. (\%) & $15(30)$ & $18(36)$ & $0.523^{a}$ \\
\hline Previous treatment (non-responder) No. (\%) & $7(14)$ & $18(36)$ & $0.011^{\mathrm{a}}$ \\
\hline Genotype (1a), No. (\%) & $29(41)$ & $41(57)$ & $0.009^{a}$ \\
\hline HCV RNA (<600 000 IU/ml), No. (\%) & $25(50)$ & $16(32)$ & $0.067^{\mathrm{a}}$ \\
\hline $\mathrm{WBC}, \mathrm{mm}^{3}$, mean $\pm \mathrm{SD}$ & $6164 \pm 1926$ & $5890 \pm 1820$ & $0.467^{b}$ \\
\hline $\mathrm{PMN}, \mathrm{mm}^{3}$, mean $\pm \mathrm{SD}$ & $3441 \pm 1297$ & $3272 \pm 1357$ & $0.527^{\mathrm{b}}$ \\
\hline $\mathrm{Hb}, \mathrm{g} / \mathrm{dl}$, mean $\pm \mathrm{SD}$ & $14.8 \pm 1.7$ & $14.4 \pm 1.8$ & $0.308^{b}$ \\
\hline PLT, $\mathrm{mm}^{3}$, mean \pm SD & $196020 \pm 73984$ & $180700 \pm 67382$ & $0.282^{b}$ \\
\hline AST ( $\geq 40 \mathrm{U} / \mathrm{L})$, No. (\%) & $34(68)$ & $30(60)$ & $0.405^{\mathrm{a}}$ \\
\hline $\operatorname{ALT}(\geq 40 \mathrm{U} / \mathrm{L})$, No. (\%) & $38(76)$ & $36(72)$ & $0.648^{\mathrm{a}}$ \\
\hline AST/ALT > 1, No. (\%) & $16(32)$ & $11(22)$ & $0.260^{\mathrm{a}}$ \\
\hline APRI $\geq 1.5$, No. (\%) & $43(52)$ & $40(48)$ & $0.424^{\mathrm{a}}$ \\
\hline End of treatment leukopenia ${ }^{c}$, No. (\%) & $26(52)$ & $25(50)$ & $0.841^{\mathrm{a}}$ \\
\hline End of treatment neutropenia d, No. (\%) & $3(6)$ & $2(4)$ & $0.716^{\mathrm{a}}$ \\
\hline End of treatment thrombocytopenia ${ }^{\mathrm{e}}$, No. (\%) & $9(18)$ & $10(20)$ & $0.761^{\mathrm{a}}$ \\
\hline
\end{tabular}

Abbreviations: ALT, alanine aminotransferase; APRI, aspartate aminotransferase (AST) to platelet ratio index; AST, aspartate aminotransferase; BMI, body mass index; Hb, hemoglobin; IVDU, intravenous drug user; PLT, platelets; PMN, polymorphoneuclear cells; WBC, white blood cells

${ }^{a}$ Chi square test

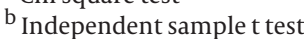

${ }^{c}$ End of treatment leukopenia: WBC $<3000 / \mathrm{mm} 3$

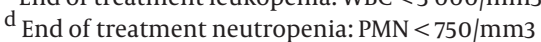

${ }^{\mathrm{e}}$ End of treatment thrombocytopenia: platelet $<100000 / \mathrm{mm} 3$

(64\%) and 74 patients (74\%), respectively. The AST/ALT was higher than 1 in 27 patients (27\%). In addition, 59 patients (59\%) demonstrated an HCV RNA level higher than 600000 $\mathrm{IU} / \mathrm{ml}$. Table 1 shows patient characteristics at the outset of the study.

\subsection{Response to Antiviral Therapy}

In terms of the ultimate outcomes, 12 patients (12\%) (CI95\%:

7-20\%) were non-responders, 16 patients (16\%) (CI95\%:10-24\%) were breakthrough, 22 (22\%) (CI95\%: 15-31\%) suffered from a relapse and 50 (50\%) (CI95\%: 40-60\%) had reached SVR. SVR occurred in 31 (56\%) of the naïve treatment patients, in 12 (60\%) of relapse patients and in seven patients $(28 \%)$ of nonresponder to previous treatment with conventional interferon (IFN). In addition, 88 patients (88\%) had EVR with positive SVR occurring in 50 (57\%) cases. Table 2 shows antiviral treatment outcomes in patients with a prior treatment history and HCV genotype. Table 3 compares patient characteristics and entry lab test results between SVR and non-SVR groups. As can be seen, SVR mostly occurs in patients who were aged 
Table 4. Predictors of Sustained Virological Response (SVR) in Multivariate Analysis

\begin{tabular}{lll}
\hline Predictor & Odd's Ratio & CI 95\% \\
\hline Age $\leq \mathbf{4 0}$ year & 3.74 & $1.52-9.22$ \\
Genotype non-1a & 3.71 & $1.40-9.81$ \\
\hline HCV RNA $<\mathbf{6 0 0 ~ 0 0 0 ~ I U / m l}$ & 2.52 & $1.03-6.15$ \\
\hline
\end{tabular}

Nagelkerke R-square $=0.232$

\begin{tabular}{ll}
\hline Table 5. The Prevalence of Drug Complications & \\
\hline & No. (\%) \\
\hline Fatigue & $74(74)$ \\
\hline Myalgia & $68(68)$ \\
\hline Depression & $39(39)$ \\
\hline Headache & $38(38)$ \\
\hline Flu like & $37(37)$ \\
\hline Fever & $31(31)$ \\
\hline Itching & $25(25)$ \\
\hline GI symptoms & $21(21)$ \\
\hline Hair loss & $16(16)$ \\
\hline Chills & $10(10)$ \\
\hline Rash & $8(8)$ \\
\hline Insomnia & $7(7)$ \\
\hline Dry skin & $7(7)$ \\
\hline
\end{tabular}

40 years or lower, who were less likely to be non-responders to previous treatments, who had genotypes other than 1a and who mostly had a baseline HCV RNA of less than 600 $000 \mathrm{IU} / \mathrm{ml}$. Predictor variables included significant variables found in the univariate analyses $(P<0.1)$ and the outcome variables, which also included reaching SVR, were entered into the logistic regression analysis using the forward conditional method. Table 4 shows the results of the multivariate analysis along with the odds ratio (OR) and CI95\%. One may infer that an age lower-than-40, a non-1a genotype and an HCVRNAless than $600000 \mathrm{IU} / \mathrm{ml}$ were the best predictors of SVR in decreasing order of strength.

\subsection{Drugs Dosage and Complications}

Drug dosage for 14 patients (14\%) was reduced during the study (ribavirin in five patients, peginterferon in seven patients, and both medications in two patients). The treatment of two patients was terminated at the ninth month, one due to intolerance of the medication and another because of occurrence of lichen planus. Mortality and loss at follow-up was zero. Hemoglobin levels never dropped below $7 \mathrm{~g} / \mathrm{dl}$ in any of the patients involved in this study. At the end of the treatment, 51 patients (51\%) suffered from leukopenia, five (5\%) from neutropenia and 19 (19\%) from thrombocytopenia. No major abnormalities were seen in; liver, kidney and thyroid tests and/or lipid profiles. Table 5 shows the prevalence of drug complications in patients.

\section{Discussion}

The findings of the present study show that half of the patients receiving a combined peginterferon $\alpha-2 a$ and ribavirin treatment reached SVR, and these rates were different among the various genotypes. The highest SVR was observed in patients with genotype 3a, while the lowest SVR was identified in patients with genotype 1a. In addition, age, virus genotype and the baseline viral load, proved to be strong SVR predictors. In fact, an age less than 40 years, non-1a genotypes and viral loads of less than $600000 \mathrm{IU} / \mathrm{ml}$ correlated with a higher SVR. However, our study did not show endof-the-treatment; leukopenia, neutropenia, thrombocytopenia, and also the APRI as predictors of reaching SVR. Evidence shows that the majority of patients with SVR sustain negative HCVRNA for years. Such patients indicate a reduced necroinflammatory process and a slight reduction in the reversible components of fibrosis. In addition, such patients show appropriate long-term biochemical and histological outcomes (3). Furthermore, SVR can lead to improved quality of life (24). Therefore, reaching SVR remains an important goal for HCV patients.

Studies in the past decade have showed that using peginterferon instead of interferon in combination with ribavirin in the treatment of HCV patients leads to improved treatment outcomes in these patients with ETR and SVR rates increasing to $69 \%$ and $56 \%$, respectively, in patients with different genotypes (9). In addition, peginterferon is shown to have increased SVR in patients with genotype 1 to $52 \%$ and to $80 \%$ in patients with genotypes 2 or $3(25,26)$. Nevertheless, mixed treatment results have been observed in different patient populations. In a recent study, McHutchinson et al. reported an SVR of $40.9 \%$ in 3070 patients with genotype 1 (27). Rumi et al. observed an SVR of 66\% (among 431 patients with genotypes 1, 2, 3 and 4)(28). Ascione et al. administered a combined peginterferon $\alpha-2 b$ and ribavirin treatment to 320 patients with genotypes 1, 2, 3 and 4 and reported an SVR of $68.8 \%$ (29). In a retrospective study on 2378 patients, Mauss et al. reported an SVR of $57.9 \%$ in patients with genotypes 1 and 4 and an SVR of 77.3\% in patients with genotypes 2 and 3(30). Although our study showed an SVR of 50\% in patients, this difference could be accounted for by differences in patient genotypes and their treatment history.

Nevertheless, our findings are to some extent, in line, with those of previous studies conducted locally. One example is Alavian's study on 52 patients that showed an SVR of 53.8\%, although their genotypes were not included as a possible variable (18). In addition, in that study, response to treatment among naïve patients was reported to be $62.9 \%$ (18), while our study records a lower level of $56 \%$. Zali et al. conducted a study on 57 patients (some suffering from thalassemia or hemophilia) and reported an SVR of 50\% in all patients and $66.7 \%$ in patients with a prior treatment history (23). In a similar study in 2004, Daryani et al. reported an SVR of 78.3\% in 23 patients (21). Although their result is significantly higher 
than similar studies in Iran and in other countries, it could be justified by the exclusion of patient genotypes and the small number of patients with a prior history of treatment. Bafandeh et al. in 2007 reported an SVR of $48 \%$ in 118 patients (20). In a study on hemophilic patients, Alavian et al. reported an SVR of 61\% (12) and finally in a study on 216 patients in Tehran, Jabari et al. recorded an SVR of 77.8\% (22) which holds a higher result to that of ours. However, one should note that in their study all patients were treatment naïve and almost half of them had genotypes 2 or 3 . In light of the results from the foregoing studies, one may state that the SVR rate in different populations, even in the same geographical location, depends on patient characteristics and viral properties. For instance, the SVR rate in American patients is less than European ones $(15,16,31,32)$ while that of Asian patients outscores both (33). In general, reaching an SVR in patients with a prior history of treatment has been reported to be $20-30 \%$ (34). In the study by Alavian et al., SVR in naïve patients was found to be $62.9 \%$ and in non-responder or relapsing patients it was found to be $35.3 \%$ (18). Our study showed an SVR proportion of $56 \%, 60 \%$ and $28 \%$ in naïve, relapse and non-responder patients using conventional interferon, respectively. These results show that combination therapy with peginterferon $\alpha-2 a$ and ribavirin can be effective for a third of patients with a history of treatment. Our study also showed that the most significant predictors of SVR were; an age below 40, non-1a genotype and a viral load less than $600000 \mathrm{IU} / \mathrm{ml}$. Numerous variables have been recognized to affect a patient's response to antiviral treatment, including; age, genotype, viral load, patient weight, race and environmental factors, etc. $(12,15,16,31,32)$. Genotype has been the most important predictors in a variety of studies $(11,13,35)$. In comparison to other genotypes, genotype 1 has been associated with lower SVR $(31,32,36)$. Genotypes other than 1a have been shown to have independently 3.25-5.4 times higher chance of positive response to treatments in various clinical trials (36). The SVR rate in genotype 1 patients increased from $41 \%$ to $52 \%$ after 48 weeks of treatment $(9,36)$ while a similar regimen produced an SVR of $76 \%-84 \%$ in genotypes 2 and 3 in a treatment period of $24-48$ weeks $(9,36,37)$. Our study also showed that the chances of reaching SVR in patients with a non-1a genotype are 3.71 times higher than those of 1a genotype patients. In addition, a low viral load can be an independent predictor for SVR $(12,17,31,36)$, overshadowing basic patient characteristics as predictors for reaching SVR (38). In our study, the chances of patients with viral load levels less than 600000 $\mathrm{IU} / \mathrm{ml}$ reaching SVR were 2.52 times higher.

Another predictor factor in reaching SVR is an age of 40 to 45 or lower $(30,39)$ which increases the chances of reaching SVR by 3.74 times. Although other studies have presented variables such as; gender, higher weight or BMI, ETR leukopenia, thrombocytopenia and neutropenia as SVR predictors $(12,36,40)$, our study did not prove these variables to be predictors. In addition, although APRI is used as an index to rate liver fibrosis (41), it failed to function as an SVR predictor in our study. In general, although different studies have introduced different SVR predictors (which may be due to different sample sizes, patients or virus characteristics), the majority of previous studies emphasize virus characteristics (ie, virus genotype or viral load) as the primary predictors of SVR in comparison with patient characteristics. Given the numerous complications, lengthy treatment period and high medical costs, it seems that determining and using SVR predictors at the outset of the HCV treatment may be beneficial (42). Hence, numerous studies are under way to find response-to-treatment predictors. An example would be detecting genetic variations of the IL28B gene in chromosome 19, which seems to be related to response-to-treatment in patients with genotype 1 (43). Although our study was one of the few studies in Iran conducted on HCV patients with advantages in terms of sample size and the multiplicity of SVR predictors, it should be noted that since patients in clinical trials were selected by exact inclusion criteria for entry into the study (selection bias), the results of these studies may not be generalized to the patient population in terms of SVR measure or SVR predictors. As a matter of fact, some studies have shown a lower SVR in general populations compared to clinical trial samples $(42,44)$. Therefore, despite improvements in antiviral therapy in recent years, the treatment of chronic hepatitis $C$ is still a challenging endeavor requiring significant improvement (17). Our findings show that achieving SVR through a combination therapy with peginterferon $\alpha-2 \mathrm{a}$ and ribavirin in chronic HCV patients is 50\%. The highest SVR rate was reported in genotype 3a patients (80\%) and the lowest rate was observed in genotype 1a patients (42\%). In addition, age, virus genotype and viral load at the outset of the treatment emerged as strong predictors of SVR.

Achieving SVR slows the progress of the disease and it is a significant treatment goal. Due to numerous medication complications, lengthy treatment period and high medical costs associated with the treatment of these patients, further research is strongly recommended in order to investigate other likely SVR predictors and to find new drugs that may increase SVR rates in different patient populations.

\section{Acknowledgments}

The authors express special appreciation to the staff of the Tehran Hepatitis Center, especially Mrs. Mahtab Najafabadi and Mr. Hossein Irani. We would also like to thank Dr Davood Yadegarynia from the Infectious Diseases and Tropical Medicine Research Center, Shahid Beheshti University of Medical Sciences for his valuable comments on this manuscript.

\section{Authors' Contribution}

Najmeh Namazee provided study concepts and design, conducted clinical study and data collection and data analysis. She also prepared the manuscript and monitored the integrity of the entire study. Shahnaz Sali provided study concepts and design and conducted clinical study, data collection and manuscript revision. Sorour Asadi, Mostafa Shafiei, and Bita Behnava conducted clinical study and data 
collection. Seyed Moayed Alavian provided study concepts and design and helped prepare and edit the manuscript. He also monitored the integrity of the entire study.

\section{Financial Disclosure}

None Declared.

\section{Funding/Support}

This study has been supported by the Research Center for Gastroenterology and Liver Diseases, Baqiatallah University of Sciences, Tehran, Iran.

\section{References:}

1. National Institutes of Health Consensus Development Conference Statement: Management of hepatitis C: 2002-June 10-12, 2002. Hepatology. 2002;36(5 Suppl1):S3-20.

2. Alavian SM, Mirmomen S, Lankarani KB, Adibi P, Merat S. What is the optimal treatment? Hepat Mon. 2004;4(1):5-6.

3. Alavian SM. Management Of Hepatitis C Infection: Regional Guideline. Hepat Mon. 2004;4(4):1-10.

4. Berenguer J, Alvarez-Pellicer J, Martin PM, Lopez-Aldeguer J, VonWichmann MA, Quereda C, et al. Sustained virological response to interferon plus ribavirin reduces liver-related complications and mortality in patients coinfected with human immunodeficiency virus and hepatitis C virus. Hepatology. 2009;50(2):407-13.

5. Breitenstein S, Dimitroulis D, Petrowsky H, Puhan MA, Mullhaupt B, Clavien PA. Systematic review and meta-analysis of interferon after curative treatment of hepatocellular carcinoma in patients with viral hepatitis. BrJSurg. 2009;96(9):975-81.

6. Singal AK, Singh A, Jaganmohan S, Guturu P, Mummadi R, Kuo YF, et al. Antiviral therapy reduces risk of hepatocellular carcinoma in patients with hepatitis C virus-related cirrhosis. Clin Gastroenterol Hepatol.2010;8(2):192-9.

7. Giannini EG, Basso M, Savarino V, Picciotto A. Sustained virological response to pegylated interferon and ribavirin is maintained during long-term follow-up of chronic hepatitis $\mathrm{C}$ patients. Aliment Pharmacol Ther. 2010;31(4):502-8.

8. Swain MG, Lai MY, Shiffman ML, Cooksley WG, Zeuzem S, Dieterich DT, et al. A sustained virologic response is durable in patients with chronic hepatitis $C$ treated with peginterferon alfa-2a and ribavirin. Gastroenterology.2010;139(5):1593-601.

9. Fried MW, Shiffman ML, Reddy KR, Smith C, Marinos G, Goncales FL, Jr., et al. Peginterferon alfa-2a plus ribavirin for chronic hepatitis $C$ virus infection. NEngl J Med. 2002;347(13):975-82.

10. Muir AJ, Bornstein JD, Killenberg PG. Peginterferon alfa-2b and ribavirin for the treatment of chronic hepatitis $\mathrm{C}$ in blacks and non-Hispanic whites. NEngl JMed.2004;350(22):2265-71.

11. Al Ashgar H, Helmy A, Khan MQ, Al Kahtani K, Al Quaiz M, Rezeig M, et al. Predictors of sustained virological response to a 48-week course of pegylated interferon alfa-2a and ribavirin in patients infected with hepatitis C virus genotype 4. Ann Saudi Med.2009;29(1):4-14

12. Alavian SM, Tabatabaei SV, Keshvari M, Behnava B, Miri SM, Elizee PK, et al. Peginterferon alpha-2a and ribavirin treatment of patients with haemophilia and hepatitis $C$ virus infection: a single-centre study of 367 cases. Liver Int. 2010;30(8):1173-80.

13. Hsu CS, Liu CH, Liu CJ, Chen CL, Lai MY, Chen PJ, et al. Factors affecting early viral load decline of Asian chronic hepatitis $\mathrm{C}$ patients receiving pegylated interferon plus ribavirin therapy. Antivir Ther. 2009;14(1):45-54

14. Jensen DM, Marcellin P, Freilich B, Andreone P, Di Bisceglie A, Brandao-Mello CE, et al. Re-treatment of patients with chronic hepatitis C who do not respond to peginterferon-alpha2b: a randomized trial. Ann Intern Med. 2009;150(8):528-40.

15. Rodriguez-Torres M, Jeffers LJ, Sheikh MY, Rossaro L, Ankoma-Sey V, Hamzeh FM, et al. Peginterferon alfa-2a and ribavirin in Latino and non-Latino whites with hepatitis C. NEngl J Med. 2009;360(3):257-67.

16. Satapathy SK, Lingisetty CS, Proper S, Chaudhari S, Williams S. Equal- ly poor outcomes to pegylated interferon-based therapy in African Americans and Hispanics with chronic hepatitis C infection. J Clin Gastroenterol. 2010;44(2):140-5.

17. Mihm U, Herrmann E, Sarrazin C, Zeuzem S. Review article: predicting response in hepatitis $\mathrm{C}$ virus therapy. Aliment Pharmacol Ther. 2006;23(8):1043-54.

18. Alavian SM, Hajarizadeh B, Hajibeigi B, Doroudi T, Hamadanizadeh AK, Abar K. Efficacy and Safety of Pegylated Interferon Alfa-2a plus Ribavirin for Treatment of Chronic Hepatitis C and Cirrhosis in Iranian. Hepat Mon. 2004;4(7):53-8.

19. Alavian SM, Miri SM, Keshvari M, Elizee PK, Behnava B, Tabatabaei SV, et al. Distribution of hepatitis $C$ virus genotype in Iranian multiply transfused patients with thalassemia. Transfusion. 2009;49(10):21959.

20. Bafandeh Y, Saberi Firouzi M, Bagheri Lankarani K. [Evaluation of Combination Therapy with Interferon and Ribavirin in Patients with Chronic Hepatitis C: A Genotype Based Study]. J Mazandaran Univ Med Sci. 2007;17(57):9-16.

21. Ebrahimi Daryani N, Haghpanah B, Sayyah AR, Hashtroudi AS, Bashashati M, Poursamimi P, et al. he Efficacy and Side Effects of Therapy Peginterferon Alpha-2a (PEGASYS) Combined with Ribavirin in Chronic HepatitisC Patients: an open label Clinical Trial. Hepat Mon. 2004;4(7):71-4

22. Jabari H, Zamani F, Hatami K, Sheikholeslami A, Fakharzadeh E, Shahzamani K, et al. Pegaferon in hepatitis C: Results of a Multicenter Study. MEJDD. 2011;3(2):110-4.

23. Zali MR, Mohaghegh Shalmani H, Norouzinia M, Alizadeh MA, al e. Peginterferon Alfa-2a (Pegasys) and Ribavirin in the Treatment of Chronic Hepatitis C. Hepat Mon. 2004;4(7):75-8.

24. Younossi Z, Kallman J, Kincaid J. The effects of HCV infection and management on health-related quality of life. Hepatology. 2007;45(3):806-16.

25. Ferenci P, Formann E, Laferl H, Gschwantler M, Hackl F, Brunner H, et al. Randomized, double-blind, placebo-controlled study of peginterferon alfa-2a (40KD) plus ribavirin with or without amantadine in treatment-naive patients with chronic hepatitis $C$ genotype 1 infection. J Hepatol. 2006;44(2):275-82.

26. Jacobson IM, Brown RS, Jr., Freilich B, Afdhal N, Kwo PY, Santoro J, et al. Peginterferon alfa-2b and weight-based or flat-dose ribavirin in chronic hepatitis $C$ patients: a randomized trial. Hepatology. 2007;46(4):971-81.

27. McHutchison JG, Lawitz EJ, Shiffman ML, Muir AJ, Galler GW, McCone $\mathrm{J}$, et al. Peginterferon alfa-2b or alfa-2a with ribavirin for treatment of hepatitis C infection. NEngl JMed. 2009;361(6):580-93.

28. Rumi MG, Aghemo A, Prati GM, D’Ambrosio R, Donato MF, Soffredini $\mathrm{R}$, et al. Randomized study of peginterferon-alpha2a plus ribavirin vs peginterferon-alpha2b plus ribavirin in chronic hepatitis C. Gastroenterology. 2010;138(1):108-15.

29. Ascione A, De Luca M, Tartaglione MT, Lampasi F, Di Costanzo GG Lanza AG, et al. Peginterferon alfa-2a plus ribavirin is more effective than peginterferon alfa-2b plus ribavirin for treating chronic hepatitis C virus infection. Gastroenterology. 2010;138(1):116-22.

30. Mauss S, Hueppe D, John C, Goelz J, Heyne R, Moeller B, et al. Estimating the likelihood of sustained virological response in chronic hepatitis C therapy.JViral Hepat. 2011;18(4):e81-90.

31. McHutchison JG, Gordon SC, Schiff ER, Shiffman ML, Lee WM, Rustgi $\mathrm{VK}$, et al. Interferon alfa-2b alone or in combination with ribavirin as initial treatment for chronic hepatitis C. Hepatitis Interventional Therapy Group. N Engl J Med.1998;339(21):1485-92.

32. Poynard T, Marcellin P, Lee SS, Niederau C, Minuk GS, Ideo G, et al. Randomised trial of interferon alpha2b plus ribavirin for 48 weeks or for 24 weeks versus interferon alpha2b plus placebo for 48 weeks for treatment of chronic infection with hepatitis $C$ virus. International Hepatitis Interventional Therapy Group (IHIT). Lancet. 1998;352(9138):1426-32.

33. McHutchison JG, Poynard T, Pianko S, Gordon SC, Reid AE, Dienstag J, et al. The impact of interferon plus ribavirin on response to therapy in black patients with chronic hepatitis C. The International Hepatitis Interventional Therapy Group. Gastroenterology. 2000;119(5):131723.

34. Shiffman ML, Di Bisceglie AM, Lindsay KL, Morishima C, Wright EC, Everson GT, et al. Peginterferon alfa-2a and ribavirin in patients with 
chronic hepatitis $\mathrm{C}$ who have failed prior treatment. Gastroenterology. 2004;126(4):1015-23; discussion 947.

35. Testino G, Sumberaz A, Ancarani AO, Borro P, Ravetti G, Ansaldi F, et al. Influence of body mass index, cholesterol, triglycerides and steatosis on pegylated interferon alfa-2a and ribavirin treatment for recurrent hepatitis $\mathrm{C}$ in patients transplanted for $\mathrm{HCV}$ and alcoholic cirrhosis. Hepato Gastroenterol. 2009;56(90):501-3.

36. Hadziyannis SJ, Sette H, Jr., Morgan TR, Balan V, Diago M, Marcellin $\mathrm{P}$, et al. Peginterferon-alpha2a and ribavirin combination therapy in chronic hepatitis C: a randomized study of treatment duration and ribavirin dose. Ann Intern Med.2004;140(5):346-55.

37. Zeuzem S, Hultcrantz R, Bourliere M, Goeser T, Marcellin P, SanchezTapias J, et al. Peginterferon alfa-2b plus ribavirin for treatment of chronic hepatitis $C$ in previously untreated patients infected with HCV genotypes 2 or 3. J Hepatol. 2004;40(6):993-9.

38. Berg T, Sarrazin C, Herrmann E, Hinrichsen H, Gerlach T, Zachoval $\mathrm{R}$, et al. Prediction of treatment outcome in patients with chronic hepatitis C: significance of baseline parameters and viral dynamics during therapy. Hepatology. 2003;37(3):600-9.

39. Idrees M, Riazuddin S. A study of best positive predictors for sus- tained virologic response to interferon alpha plus ribavirin therapy in naive chronic hepatitis C patients. BMC Gastroenterol. 2009;9:5.

40. Suwantarat N, Tice AD, Khawcharoenporn T, Chow DC. Weight loss, leukopenia and thrombocytopenia associated with sustained virologic response to Hepatitis C treatment. Int J Med Sci. 2010;7(1):36-42.

41. Wai CT, Greenson JK, Fontana RJ, Kalbfleisch JD, Marrero JA, Conjeevaram HS, et al. A simple noninvasive index can predict both significant fibrosis and cirrhosis in patients with chronic hepatitis $\mathrm{C}$ Hepatology. 2003;38(2):518-26.

42. Hansen N, Obel N, Christensen PB, Kjaer M, Laursen AL, Krarup HB, et al. Effectiveness of treatment with pegylated interferon and ribavirin in an unselected population of patients with chronic hepatitis $\mathrm{C}$ a Danish nationwide cohort study. BMC Infect Dis. 2011;11:177.

43. Tanaka Y, Nishida N, Sugiyama M, Kurosaki M, Matsuura K, Sakamoto $\mathrm{N}$, et al. Genome-wide association of IL28B with response to pegylated interferon-alpha and ribavirin therapy for chronic hepatitis C. Nat Genet. 2009;41(10):1105-9.

44. Backus LI, Boothroyd DB, Phillips BR, Mole LA. Predictors of response of US veterans to treatment for the hepatitis C virus. Hepatology. 2007;46(1):37-47. 